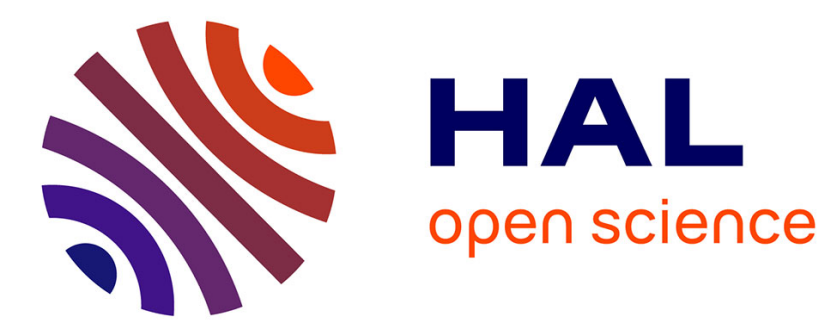

\title{
Geomagnetic field: Volcanic record of reversal
}

Jean-Pierre Valet, Carlo Laj, Piotr Tucholka, Bjorn Kurten, I O’ Brien, W G Nash, R E Benveniste

\section{To cite this version:}

Jean-Pierre Valet, Carlo Laj, Piotr Tucholka, Bjorn Kurten, I O' Brien, et al.. Geomagnetic field: Volcanic record of reversal. Nature, 1985, 316 (6025), pp.217-218. 10.1038/316217a0 . hal-03520477

\section{HAL Id: hal-03520477 \\ https://hal.science/hal-03520477}

Submitted on 11 Jan 2022

HAL is a multi-disciplinary open access archive for the deposit and dissemination of scientific research documents, whether they are published or not. The documents may come from teaching and research institutions in France or abroad, or from public or private research centers.
L'archive ouverte pluridisciplinaire HAL, est destinée au dépôt et à la diffusion de documents scientifiques de niveau recherche, publiés ou non, émanant des établissements d'enseignement et de recherche français ou étrangers, des laboratoires publics ou privés. 


\section{A molecular solution to the riddle of the giant panda's phylogeny}

O'BRIEN et al. predict "the existence of older Pliocene or even Miocene fossils of the ancestors of the giant panda". In fact, a putative ancestor was identified by Thenius ${ }^{2}$ in 1979. This is Agriarctos Kretzoi, described on mandibular dental material from the late Miocene of Hungary. This ursid shows incipient molarization of the premolars apparently foreshadowing the condition in Ailuropoda.

This is independent support of the conclusions reached by O'Brien et al., including their suggestion that Ailuropoda (with Agriarctos) may be assigned to a subfamily (Ailuropodinae) of the family Ursidae.

\section{Department of Geology, \\ University of Helsinki, \\ Snellmaninkatu 5, 00170, \\ Helsinki 17, Finland \\ 1. O'Brien, J. O., Nash, W. G., Wildt, D. E., Bush, M. E. \& Benveniste, R. E. Nature 317, 140-155 (1985). \\ 2. Thenius, E. Anz. öst. Akad. Wiss. 1979, 67-68 (1979); Z Säugetierk 44, 286-305 (1979). \\ Steens Mountain geomagnetic polarity transition is a single phenomenon}

IN their reinterpretation of the transition recorded in the Steens Mountain lavas ${ }^{1}$, Valet $e t a l^{2}$ suggest that the second phase (the 'rebound') occurred at a significantly later time than the first phase (the reverseto-normal transition). In this way they attempt to separate what is one phenomenon into two separate phenomena, and assert that the second phase is a geomagnetic excursion unrelated to the preceding reversal. Several lines of evidence indicate that there was no significant hiatus in eruptive activity in the part of the lava section on Steens Mountain sampled by us and previously by Watkins ${ }^{3}$.

First, there are no soil horizons, weathered zones or interbasaltic sedimentary rocks or sediments anywhere in the sampled section, except some negligible baked earths (tuffs, perhaps) that we found in two restricted localities stratigraphically unrelated to the limits of either of the two transition phases. Moreover, the lavas are of rather uniform composition, and the only obvious lithological variability between successive larvas is the presence or absence of large platy labradorite phenocrysts up to $4 \mathrm{~cm}$ in diameter. The occurrence of these porphyritic larvas is unrelated to any aspect of the polarity transition.

Second, Gunn and Watkins ${ }^{4,5}$ made many complete chemical analyses of the

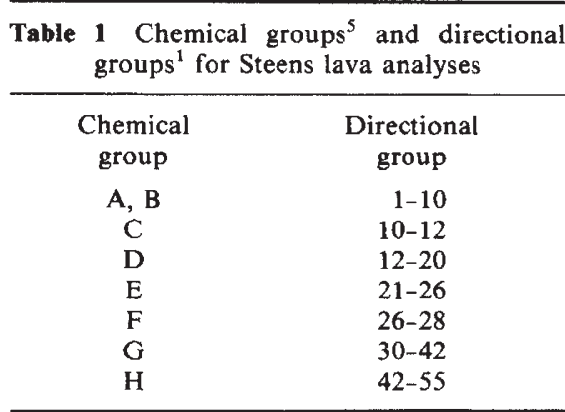

Table 2 Recalculated $\mathrm{K}$-Ar ages

\begin{tabular}{ccc}
$\begin{array}{c}\text { Watkins } \\
\text { flow } \\
\text { no. }\end{array}$ & $\begin{array}{c}\text { Directional } \\
\text { group }^{1}\end{array}$ & $\begin{array}{c}\text { Age } \\
\text { (Myr) }\end{array}$ \\
11 & $\sim 4$ & $15.5 \pm 0.15$ \\
17 & $\sim 10$ & $15.4 \pm 0.13$ \\
51 & 33 & $15.5 \pm 0.28$ \\
61 & 43 & $15.4 \pm 0.25$ \\
68 & 49 & $15.6 \pm 0.21$ \\
70 & 49 & $15.3 \pm 0.21$ \\
\hline
\end{tabular}

The uncertainty is 1 s.d. of the data.

Steens lavas. Table 1 shows how their chemical groups correspond to our directional groups. The first phase of the reversal begins with directional groups 43 and ends with group 30 , and the second phase begins with group 28 and ends with group 15 . The variations in chemical composition are uncorrelated with any aspect of the palaeomagnetic record, and several of the chemical boundaries occur within directional groups. The only possible peculiarity is that Gunn and Watkins analysed a high-alumina flow and a pyroxenerich flow in chemical group $\mathrm{F}$, which corresponds to the beginning of the second phase. These lavas, however, are perfectly correlated with the others, as demonstrated by an alumina variation diagram ${ }^{5}$.

Third, there is no discernible age difference between the top and bottom of the sampled section. We have recalculated

\section{Matters Arising}

Matters Arising is meant as a vehicle for comment and discussion about papers that appear in Nature. The originator of a Matters Arising contribution should initially send his manuscript to the author of the original paper and both parties should, wherever possible, agree on what is to be submitted. Neither contribution nor reply (if one is necessary) should be longer than 500 words and the briefest of replies, to the effect that a point is taken, should be considered. and averaged the $\mathrm{K}-\mathrm{Ar}$ ages published by Baksi et al. $^{6}$ and they are given in Table 2 (new decay constants).

Thus, the available field observations and geochemical and geochronological data directly contradict the suggestion of Valet et $a l^{2}$ that the two phases described in our article ${ }^{1}$ may not belong to a single geomagnetic process.

\section{S. GROMMÉ \\ E. A. MANKINEN* \\ M. PRÉVOT† \\ R. S. COE‡}

* US Geological Survey, 345 Middlefield $R d$,

Menlo Park, California 94025, USA

† Centre Géologique et Géophysique,

CNRS, and Université des

Sciences et Techniques,

34060 Montpellier Cedex, France

$\ddagger$ Earth Sciences Board,

University of California,

Santa Cruz, California 95064, USA

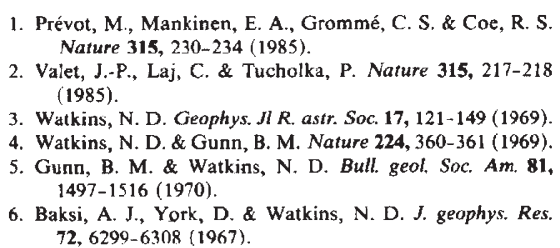

VALET, LAJ AND TUCHOLKA REPLYIn some of the reversal records that we have obtained from sedimentary sections in Greece (work partly published and presented at IAGA Praga 1985), we have also observed excursions occurring either before or after the transition. In all these cases the characteristics of the directional changes during both the polarity transition and the excursions are similar. The continuity of the sedimentary records also shows that the duration of the excursions never exceeds the time span of the transition.

In the Steens Mountain record ${ }^{1}$, the first phase is quite similar to a sedimentary reversal record but, in striking contrast to our observations, the second phase is dissimilar. Furthermore, between the two phases the geomagnetic field has recovered high intensity and dipolar direction. The authors consider the two phases as a single phenomenon. In an attempt to reconcile sedimentary and volcanic records, we have suggested ${ }^{2}$ that the widely different symmetry properties could indicate two unrelated different phenomena.

The existence of rebounds or oscillations associated with a reversal is an important problem which, as Prévot et al. suggest $^{1}$, may be crucial to our understanding of geomagnetic reversals. Clearly, what is needed is a criterion to establish when an excursion is connected to a reversal. The argument of continuity 